Original Article

\title{
STEROLS BIOACTIVITY OF RUTA GRAVEOLENS L. AND MURRAYA PANICULATA L.
}

\author{
DOHA H. ABOU BAKER ${ }^{1}$, EMAN A. IBRAHIM ${ }^{2}$, AHMED KANDEIL ${ }^{3}$, FAROUK K. EL BAZ ${ }^{* 2}$ \\ ${ }^{1}$ Medicinal and Aromatic Plant, ${ }^{2}$ Plant Biochemistry, ${ }^{3}$ Water Pollution Research, Department, National Research Centre (NRC), 33 El \\ Bohouth st. (Former El Tahrir st.), Dokki, Giza, Egypt, P. 0.12622 \\ Email: fa_elbaz@hotmail.com \\ Received: 20 Oct 2016 Revised and Accepted: 07 Dec 2016
}

\begin{abstract}
Objective: Ruta graveolens L. (R. graveolens) and Murraya paniculata L. (M. paniculata) are medicinal plants belonging to Rutaceae family have many uses in traditional medicine. The aim of the present study was to investigate sterols bioactivity of the two Rutaceae plant leaves.

Methods: Sterols of the two Rutaceae plant leaves were identified using GC/MS. The antioxidant activities of the sterols of these herbs were evaluated by three different methods; free radical scavenging using 2,2'-Azino-bis (3-ethylbenzthiazoline-6-sulfonic acid) (ABTS), 1,1-Diphenyl-2picryl-hydrazyl (DPPH) and total antioxidant activity. The anticancer activity of the sterols was determined by MTT assay against colorectal cancer HCT116, breast cancer MCF7, liver cancer HepG2 and lung cancer A549 cell lines. Anti-inflammatory activity was evaluated using albumin denaturation assay and antiviral activities against H5N1 virus were carried out using plaque reduction assay.

Results: GC/MS assay showed $\beta$-Sitosterol (36\%) as the most abundant sterols of R. graveolens followed by stigmasterol (18\%), while stigmasterol (25.2\%) was the most abundant one of M. paniculata steroids. The anti-inflammatory potential of R. graveolens steroids was significantly higher than that of diclofenac sodium (standard drug). M. paniculata sterols have higher antiviral activity (IC $50=0.15 \mathrm{of} \mu \mathrm{g} / \mathrm{ml}$ ) than R. graveolens sterols $\left(\mathrm{IC}_{50}=7.8 \mathrm{of} \mu \mathrm{g} / \mathrm{ml}\right)$. The sterols of $R$. graveolens showed anticancer activity against MCF7 and A549 cells with inhibition 84.3 and $81 \%$, at 100 $\mu \mathrm{g} / \mathrm{ml}$ respectively. While $M$. paniculata sterols showed $77.3 \%$ inhibition against A549 cells.
\end{abstract}

Conclusion: The current study suggests that the sterols of M. paniculata have more anti-viral activity than R. graveolens sterols which showed more anticancer and anti-inflammatory activities.

Keywords: Ruta graveolens L., Murraya paniculata L., phytosterols, bioactivity

(C) 2017 The Authors. Published by Innovare Academic Sciences Pvt Ltd. This is an open access article under the CC BY license (http://creativecommons.org/licenses/by/4. 0/ DOI: http://dx.doi.org/10.22159/ijpps.2017v9i2.15790

\section{INTRODUCTION}

Therapeutic plants are broadly utilised as a part of the treatment of many diseases. So, there are increasing interests to use plants in traditional medicine. They show more natural movement than manufactured medications without side effects, easily available, safer and cheaper. In the treatment of oxidative diseases such as inflammation, cancer and aging, antioxidant therapy has earned an importance. Reactive oxygen species (ROS) increase inflammation by the release of tumor necrosis factors, which stimulate neutrophil and macrophages. Thus, ROS are important mediators that stimulate inflammatory processes and consequently, their neutralisation by radical scavengers can reduce inflammation [1].

Rutaceae family are known for their high diversity of secondary metabolites includinglavonoids, alkal oids, terpenes, limonoids and coumarins; these bioactive groups show remarkable medicinal effects [2]. R. graveolens and M. paniculata considered the most important traditional medicine in Rutaceae family [3]. They have antidiabetic, antifungal, antiandrogenic, antirheumatic pain, contraceptive, anti-hangover, antidote and insecticide effects [4-12]. Rutaceace popular with its secondary metabolites such as; alkaloids (graveoline, dictamnine, $\gamma$ fagarine, skimmianine, rutalinium and furacridone); coumarins (bergaptene); flavonoids (rutin); essential oil (2-undecyl acetate, 2-nonylacetate and 2-nonanone) [13].

Phytosterols are cholesterol-like molecules found in herbs and plants, the most common phytosterols are stigmasterol, $\beta$-sitosterol, and campesterol. They have been shown to reduce cancer, oxidation, inflammation, viral infection and blood cholesterol. On the basis of the uses of these compounds in traditional medicine, the present work was focused on R. graveolens and M. paniculata sterols to study their antioxidant, anti-inflammatory, antiviral and anticancer activities.

\section{MATERIALS AND METHODS}

Plant material

Plants were adopted from horticulture Dept. Agriculture Research Centre. They were identified by phytochemistry Dept. National Research Centre. The plants were air-dried at room temperature.

\section{Determination of total lipid content}

$10 \mathrm{~g}$ of air-dried fine powder of each Rutaceae plant leaves were extracted by petroleum ether $40-60{ }^{\circ} \mathrm{C}$ using Soxhlet apparatus till complete extraction. The solvent was evaporated by rotary evaporator at $40^{\circ} \mathrm{C}$ till dryness then the residue was kept in vacuum desiccators till constant weight and the concentration of total lipids were calculated [14].

\section{Separation of unsaponifiable matter and fatty acids}

One $\mathrm{ml}$ oil of the two species was saponified with methanolic KOH $(20 \mathrm{ml}, 10 \%)$ at $80^{\circ} \mathrm{C}$ for $3 \mathrm{~h}$ under reflux. The unsaponifiable matter of each oil was extracted with ether $(4 \mathrm{x} 10 \mathrm{ml})$, washed several times with distilled water, dried over anhydrous sodium sulphate. Then the solvent was evaporated and the unsaponifiable matter was quantified (g) and kept for further analysis.

\section{Identification of the unsaponifiable matter}

The unsaponifiable matters of the two Rutaceae plant leaves were identified using GC/MS, with the following conditions:

Hewlett Packard HP 6890 apparatus equipped with HP-1 methyl siloxane capillary column $(0.25 \mathrm{~mm} \times 30 \mathrm{~m})$, using flame ionisation detector (FID), and nitrogen was used, as a carrier gas. Nitrogen, hydrogen and air gases were set at flow rates 30,30 and 300 $\mathrm{ml} / \mathrm{min}$, respectively. Oven temperature was programmed from 70 $280^{\circ} \mathrm{C}$ at rate $8^{\circ} \mathrm{C} / \mathrm{min}$. Temperatures of detector and injectors were 300 and $250^{\circ} \mathrm{C}$, respectively. The hydrocarbon and sterol compounds 
were identified by comparing the relative retention times of the separated components with those of available standard materials injected under the same conditions. The quantitative estimation of each compound was based on the area of the recorded peak area.

\section{Antioxidant activity}

The antioxidant activity was determined using the following methods:-

\section{ABTS free radical scavenging assay}

The ABTS free radical scavenging assay was carried out according to Arnao et al. [15]. Potassium persulfate $(2.6 \mathrm{mmol})$ was added to 7.4 mmol of $\mathrm{ABTS}^{+}$and kept for $12-16 \mathrm{~h}$ at room temperature in the dark. The ABTS+solution $(1 \mathrm{ml})$ was diluted with $60 \mathrm{ml}$ methanol to an absorbance of $1.1 \pm 0.02$ at $734 \mathrm{~nm}$ before analysis. $\mathrm{ABTS}^{+}$solution $(2.80 \mathrm{ml})$ was added to sample fractions $(0.150 \mathrm{ml}, 50-150 \mu \mathrm{g} / \mathrm{ml})$. After incubation for $2 \mathrm{~h}$ in the dark, the absorbance was measured at $734 \mathrm{~nm}$. Ascorbic acid was used as the positive control. The $\mathrm{ABTS}^{+}$free radical-scavenging capacity (\%) was calculated using the following equation:

$$
\text { ABTS scavenging activity } \%=\left[1-\frac{A_{1}-A_{2}}{A_{0}}\right] \times 100
$$

Where, $A_{0}$ was the absorbance of the control (without sample), $A_{1}$ was the absorbance in the presence of the sample and $A_{2}$ was the absorbance without $\mathrm{ABTS}^{+}$).

\section{DPPH free radical scavenging assay}

The ability of different sterols from the two Rutaceae plant to scavenge DPPH free radical were determined according to Ye et al. [16] method. Briefly, $0.1 \mathrm{mmol}$ of sterols DPPH solution was prepared to give the initial absorbance value of 0.993 at $517 \mathrm{~nm}$. The different concentration of samples (in $0.1 \mathrm{ml}$ ) of each sample (with appropriate dilution if necessary) was added to $3.0 \mathrm{ml}$ of ethanolic DPPH solution. After incubation for $30 \mathrm{~min}$ in the dark, the absorbance was measured at $517 \mathrm{~nm}$. The DPPH scavenging activity was calculated using the following formula:

$$
\text { DPPH scavenging activity } \%=\left[1-\frac{A_{\text {sample }}-A_{\text {blank }}}{A_{\text {control }}}\right] \times 100
$$

\section{Total antioxidant capacity}

The total antioxidant assay was carried out according to Prieto et al. [17]. One $\mathrm{ml}$ of different extracts from the sterols of the two Rutaceae sp. (100 to $400 \mu \mathrm{g} / \mathrm{ml}$ ) were mixed with $3 \mathrm{ml}$ of reagent solution $(0.6 \mathrm{M}$ sulfuric acid, $28 \mathrm{mmol}$ sodium phosphate and 4 mmol ammonium molybdate). The tubes were capped and incubated at $95^{\circ} \mathrm{C}$ for $90 \mathrm{~min}$. After cooling, the absorbance of each sample was measured at $695 \mathrm{~nm}$. Standard series concentrations of ascorbic acid were treated as the sample.

\section{Anti-inflammatory activity}

Anti-inflammatory of the sterols of the two Rutaceae sp. was tested using the method of Rahman et al. [18]. The different concentrations of both plant sterols and standard drug; diclofenac sodium $(50,100$, $150,200 \mathrm{ug} / \mathrm{ml}$ ) were mixed with $0.45 \mathrm{ml}$ bovine albumin serum. The sample extracts were incubated at $37^{\circ} \mathrm{C}$ for $20 \mathrm{~min}$ and then heated to $57^{\circ} \mathrm{C}$ for $3 \mathrm{~min}$ after cooling the samples was added $2.5 \mathrm{ml}$ phosphate buffer $\mathrm{pH}$ 6.4. The absorbance was measured using UVvisible spectrophotometer at $255 \mathrm{~nm}$.

\section{Antiviral activity}

\section{Cytotoxicity assay}

The cytotoxic effect of each sterol was tested individually in MadinDarby Canine kidney cells (MDCK) (friendly obtained from St. Jude Children's Research Hospital) using the 3-(4, 5-dimethylthiazol-2yl)-2, 5-diphenyltetrazolium bromide (MTT, Lonza) with minor modification as previously described [19]. Briefly, MDCK cells were seeded in 96 well culture plates and incubated for $24 \mathrm{~h}$ at $37{ }^{\circ} \mathrm{C}$ in $5 \% \mathrm{CO}_{2}$. After $24 \mathrm{~h}$ post culture, the cells were treated with desired concentrations of the tested compounds in triplicates. After further
$24 \mathrm{~h}$, the medium was aspirated and cell monolayer was washed with phosphate buffer saline (PBS) 3 times then MTT solution $(20 \mu \mathrm{l}$ of $5 \mathrm{mg} / \mathrm{ml}$ stock solution) was added to each well and incubated at $37^{\circ} \mathrm{C}$ for $4 \mathrm{~h}$. A volume of $200 \mu \mathrm{l}$ of DMSO was added to each well to dissolve formazan crystals. The absorbance of formazan solutions was measured at $\lambda \max 540 \mathrm{~nm}$. The percentage of cytotoxicity of each sterol was determined with the following equation:

Cytotoxicity $\%=\frac{\text { Absorbance of cell without treatment-Absorbance of cell with treatment }}{\text { Absorbance of cell without treatment }} \times 10 \mathrm{C}$

The plot of cytotoxicity \% versus concentration of tested sterols was used to calculate the concentration which exhibited $50 \%$ cytotoxicity $\left(\mathrm{TC}_{50}\right)$.

\section{Plaque reduction assay}

Antiviral activities of tested sterols were carried out using plaque reduction assay as previously described [20]. Briefly, MDCK cells were seeded in 6 well culture plates $\left(10^{5} \mathrm{cells} / \mathrm{ml}\right)$ and incubated for $24 \mathrm{~h}$ at $37{ }^{\circ} \mathrm{C}$ in $5 \% \mathrm{CO}_{2}$. Previously titrated A/duck/ Egypt/ Q5569D/2012(H5N1) virus was diluted to optimal virus dilution that gave countable plaques and mixed with the safe concentration of each tested sterols then incubated for $1 \mathrm{hr}$ at $37^{\circ} \mathrm{C}$ before being added to the cells. Growth medium was removed from the 6 well cell culture plates and virus-compound mixtures were inoculated in duplicates, After $1 \mathrm{hr}$ contact time for virus adsorption, $3 \mathrm{ml}$ of DMEM supplemented with $2 \%$ agarose, $1 \%$ Antibiotic-antimycotic mixture and $4 \%$ bovine serum albumin (BSA, Sigma) was added onto the cell monolayer, plates were left to solidify and incubated at $37^{\circ} \mathrm{C}$ till formation of viral plaques ( $3 \mathrm{~d}$ ). $10 \%$ Formalin was added to each well for $1 \mathrm{~h}$ then over layer was removed. Fixed cells were stained with $0.1 \%$ crystal violet in distilled water. Control untreated virus was included in each plate. Finally, plaques were counted and the percentage of reduction in virus count was recorded as following:

$$
\% \text { inhibition }=\frac{\text { Viral count (untreated)-viral count (treated) }}{\text { Viral count (untreated) }} \times 100
$$

\section{Cytotoxic effect on human cell lines}

Cell viability was assessed by the mitochondrial-dependent reduction of yellow MTT (3-(4,5-dimethylthiazol-2-yl)-2,5-diphenyl tetrazolium bromide) to purple formazan [21].

Procedure: All the following procedures were done in a sterile area using a Laminar flow cabinet biosafety class II level (Baker, SG403INT, Sanford, ME, USA). Cells were suspended in RPMI 1640 medium for (HepG2, MCF-7 and HCT116) and DMEM for A549, 1\% antibiotic-antimycotic mixture $(10,000 \mathrm{U} / \mathrm{ml}$ Potassium Penicillin, $10,000 \mu \mathrm{g} / \mathrm{ml}$ Streptomycin Sulfate and $25 \mu \mathrm{g} / \mathrm{ml}$ Ampho-tericin B) and $1 \% \mathrm{~L}$-glutamine at $37{ }^{\circ} \mathrm{C}$ under $5 \% \mathrm{CO}_{2}$.

Cells were batch cultured for $10 \mathrm{~d}$, then seeded at a concentration of $10 \times 10^{3}$ cells/well in fresh complete growth medium in 96-well microtiter plastic plates at $37{ }^{\circ} \mathrm{C}$ for $24 \mathrm{~h}$ under $5 \% \mathrm{CO}_{2}$ using a water-jacketed Carbon dioxide incubator (Sheldon, TC2323, Cornelius, OR, USA). Media was aspirated, fresh medium (without serum) was added and cells were incubated either alone (negative control) or with different concentrations of the sample to give a final concentration of (100-50-25-12.5-6.25-3.125-0.78 and $1.56 \mu \mathrm{g} / \mathrm{ml})$. After $48 \mathrm{~h}$ of incubation, the medium was aspirated, $40 \mu \mathrm{l}$ MTT salt $(2.5 \mu \mathrm{g} / \mathrm{ml})$ were added to each well and incubated for further four hours at $37^{\circ} \mathrm{C}$ under $5 \% \mathrm{CO}_{2}$. To stop the reaction and dissolving the formed crystals, $200 \mu \mathrm{l}$ of $10 \%$ Sodium dodecyl sulphate (SDS) in deionized water was added to each well and incubated overnight at $37^{\circ}$ C. A positive control which composed of $100 \mu \mathrm{g} / \mathrm{ml}$ was used as a known cytotoxic natural agent which gives $100 \%$ lethality under the same conditions $[22,23]$. The absorbance was then measured using a microplate multi-well reader (Bio-Rad Laboratories Inc., model 3350, Hercules, California, USA) at $595 \mathrm{~nm}$ and a reference wavelength of $620 \mathrm{~nm}$. A statistical significance was tested between samples and negative control (cells with vehicle) using independent t-test by SPSS 11 program. DMSO is the vehicle used for dissolution of plant extracts and its final concentration on the cells was less than $0.2 \%$. The percentage of change in viability was calculated according to the formula: 
$\%$ of viability change $=\left[\frac{\text { Reading of extract }}{\text { Reading of negative control }}-1\right] \times 100$

A probit analysis was carried for IC $_{50}$ and IC $_{90}$ determination using SPSS 11 program.

\section{Statistical analysis}

Results are expressed as mean value of three replicate. Data were statistically analysed through analysis of variance (ANOVA) and Duncan's test at $\mathrm{P}>0.01$ using CoStat-Statistics Software.

\section{RESULTS AND DISCUSSION}

The data obtained from GC/MS analysis of the unsaponifiable matter of the sterols extracted from R. graveolens L. and M. paniculata L. are presented in table (1). The highest content of the sterols identified are $\beta$-sitosterol (36\%) and stigmasterol (18\%) followed by campesterol (8.99\%) for R. graveolens. While the major phytosterol in M. paniculata are stigmasterol (25.2\%) followed by eicosane (10.9\%) and octadecane (10.5\%).
Dealing with sterols, the unsaponifiable matter of most Ruteceae species contained campesterol, stigmasterol and $\beta$-sitosterol [24]. Phytosterol has been demonstrated to relive hypercholesterolemia and control cardiovascular diseases, oxidative stress, inhibit inflammation and inhibit cancer. Many studies demonstrated that there are a relation between intake of phytosterol and a decrease the risk of some dangerous disease $[25,26]$. Many studies have embroiled oxidative cell damage emerging from an imbalance between free radicals and oxidative defence as the essential driver of dangerous diseases [27].

\section{Antioxidant activity}

The present study demonstrated powerful antioxidant activity in a dose-dependent relationship as shown in the table (2). Table (2) demonstrated that all samples possesses ABTS radical scavenging activity less than $60 \%$ at $150 \mu \mathrm{g} / \mathrm{ml}$ and less than ascorbic acid as standard antioxidant (122.3\%). The scavenging activity at 150 $\mu \mathrm{g} / \mathrm{ml}$ can be arranged in the following order: ascorbic acid $>R$. graveolens $>M$. paniculata. There are significant differences due to the scavenging activity by ABTS.

Table 1: GC/MS analysis of unsaponifiable matter of the sterols fraction of $R$. graveolens and M. paniculata

\begin{tabular}{|c|c|c|}
\hline \multirow[t]{2}{*}{ Compounds } & \multicolumn{2}{|c|}{ Relative percentage } \\
\hline & R. graveolens & M. paniculata \\
\hline Hexadecane & - & 7.8 \\
\hline Octadecane & 8.99 & 10.5 \\
\hline Nonadecane & 2.84 & 1.8 \\
\hline Eicosane & 0.2 & 10.9 \\
\hline Docosane & 8.95 & 7.7 \\
\hline Tricosane & 4.16 & 5.8 \\
\hline Tetracosane & 1.68 & 5.5 \\
\hline Pentacosane & 2.77 & 1.7 \\
\hline Hexacosane & 1.37 & 5.6 \\
\hline Heptacosane & 2.83 & 1.3 \\
\hline Nonacosane & 0.92 & -- \\
\hline Triocontane & 2.3 & 0.8 \\
\hline Campasterol & 8.99 & 5.5 \\
\hline Stigmasterol & 18 & 25.2 \\
\hline$\beta$-Sitosterol & 36 & 9.9 \\
\hline
\end{tabular}

Table 2: Antioxidant activity (\%) of the sterols fraction of $R$. graveolens and M. paniculata against ABTS, DPPH radical and their total antioxidant activity

\begin{tabular}{|c|c|c|c|c|c|c|c|c|c|c|}
\hline \multirow{3}{*}{$\begin{array}{l}\text { Sample } \\
\text { s }\end{array}$} & ABTS & & & DPPH & & & Total antio & dant capaci & & \\
\hline & \multicolumn{10}{|c|}{ Sample concentration $(\mu \mathrm{g} / \mathrm{ml})$} \\
\hline & 50 & 100 & 150 & 50 & 100 & 150 & 50 & 100 & 150 & 200 \\
\hline$R$. & $44.06 \pm$ & $55.08 \pm 2.1$ & $57.24 \pm 10$. & $32.85 \pm 0.7$ & $36.34 \pm 2$. & $43.635 \pm 6.6$ & $119.96 \pm 6.7$ & $135.11 \pm 2$. & $142.85 \pm 4$ & $186.04 \pm 2$. \\
\hline $\begin{array}{l}\text { graveol } \\
\text { ens }\end{array}$ & $3.19 \mathrm{~cd}$ & $1^{\mathrm{cd}}$ & $14^{\mathrm{c}}$ & $0^{c}$ & $04^{\mathrm{c}}$ & $8^{c}$ & $0^{\mathrm{h}}$ & $60^{\mathrm{fg}}$ & $50^{\mathrm{f}}$ & $02 \mathrm{~d}$ \\
\hline$M$. & $58.89 \pm$ & $54.99 \pm 10$. & $56.61 \pm 8.2$ & $47.98 \pm 11$ & $39.50 \pm 9$. & $43.13 \pm 11.6$ & $144.61 \pm 3.9$ & $160.84 \pm 3$. & $173.55 \pm$ & $201.72 \pm 1$ \\
\hline $\begin{array}{l}\text { panicul } \\
\text { ata }\end{array}$ & $11.49^{c}$ & $75^{\mathrm{cd}}$ & $7 \mathrm{~cd}$ & $45^{c}$ & $67^{c}$ & $3 c$ & $1^{\mathrm{f}}$ & 90 e & 4.01 de & $98^{c}$ \\
\hline Ascorbi & $40.76 \pm 0$ & $81.53 \pm 0.7$ & $122.3 \pm 1.1$ & $45.86 \pm 4.6$ & $84.2 \pm 4.3$ & $113.87 \pm 10$ & $127.97 \pm 8.9$ & $147.37 \pm 12$ & $230.16 \pm 6$ & $243.46 \pm 3$ \\
\hline$c$ acid & $37^{d}$ & 5 b & 3 a & $4^{c}$ & $9 \mathrm{~b}$ & $83^{a}$ & $3 \mathrm{gh}$ & $.15^{f}$ & $20^{b}$ & $56^{a}$ \\
\hline LSD & 9.84 & & & 10.98 & & & 6.63 & & & \\
\hline 0.01 & & & & & & & & & & \\
\hline
\end{tabular}

Data are represented as mean $\pm \mathrm{SD}$, Statistical analysis is carried out by two-way analysis of variance using COSTAT program, un-shared letters between brackets were a significant value between groups.

DPPH results revealed that the antioxidant activity of ascorbic acid was significantly higher than $R$. graveolens, M. paniculata sterols. No significant different between different sterols. From table (2), the data clearly showed that, all samples exhibited high scavenging activity were concentration dependent.

The results also revealed that the antioxidant capacity of the extracts can be arranged according to the total antioxidant activity in the following order: ascorbic acid, M. paniculata and $R$. graveolens. The results of antioxidant activity are agreed with the results of Valentina and Neelamegam [28] which revealed the high antioxidant potential of plant sterols. Several studies revealed the highest antioxidant activity of M. paniculata extracts [29], essential oil [30] and phenolic content [31] compared with vitamin E [32], BHT and BHA [30]. In the same time, Haraguchi [33] demonstrated that the potency of $R$. graveolens extract was nearly the same as BHT. Both $M$. paniculata and $R$. graveolens sterols demonstrated the acceptable effect in free radical scavenging activity.

\section{Anti-inflammatory activity}

Results in the table (3) showed the anti-inflammatory activity of the sterols of the Rutaceae plants under investigation, significant high percentages of an anti-inflammatory inhibition was recorded for $R$. 
graveolens at the different concentrations in a dose-dependent manner followed by diclofenac sodium and M. paniculata.

Inflammation is a complex process and various mediators eg prostaglandin, leukotrienes, etc, have been reported to be involved in the development of inflammatory diseases. The results of the present study go parallel with results obtained by Harsha and Latha [34], they found that Methanol extract of R. graveolens showed significant anti-inflammatory activity and also provide evidence for the leaves $R$. graveolens in folk treatment as an anti-inflammatory agent. The results of the current study revealed the strong antiinflammatory activity of $R$. graveolens and are in accordance with that of the findings of Ratheesh et al. [3]. They found that the alcoholic extract of R. graveolens indicated most extreme (90.9\%) restraint on carrageenan incited rodent paw edema. The impact was fundamentally $(\mathrm{P}<0.05)$ higher than that of the Voveran (standard medication $72.72 \%$ ). The highest activity of $R$. graveolens sterols may be due to $\beta$-sitosterol as the predominant sterol that accounted for $36 \%$ of the total amount of sterols. This compound was found to possess potent anti-inflammatory activity [35] similar to hydrocortisone and oxyphenbutazone when administered intraperitoneally. This compound was also orally effective against carrageenin-induced odema. Prieto et al. [36] revealed that $\beta$ sitosterol can modulate a cell-mediated edema. In another study carried out by Laidlaw [37] showed that plant sterols were found to reduce IL-6 levels which associated with inflammation possibly.

Table 3: Anti-inflammatory activity of sterols fraction of $R$. graveolens and M. paniculata

\begin{tabular}{llll}
\hline & \multicolumn{2}{l}{ Sample concentration $(\boldsymbol{\mu g} / \mathbf{m l})$} & $\mathbf{1 5 0}$ \\
\cline { 2 - 4 } & $\mathbf{5 0}$ & $\mathbf{1 0 0}$ & $\mathbf{1 5 0}$ \\
\hline Diclofenac sodium & $74.05 \pm 0.37^{\mathrm{e}}$ & $81.74 \pm 0.63^{\mathrm{d}}$ & $85.5 \pm 0.20^{\text {cd }}$ \\
R. graveolens & $66.86 \pm 4.68^{\mathrm{f}}$ & $86.74 \pm 1.54^{\mathrm{c}}$ & $101.07 \pm 1.57^{\mathrm{b}}$ \\
M. paniculata & $52.80 \pm 0.42^{\mathrm{h}}$ & $55.37 \pm 0.54^{\mathrm{gh}}$ & $57.80 \pm 2.59 \mathrm{~g}$ \\
LSD 0.01 & 2.08 & & $112.98 \pm 2.03^{\mathrm{a}}$ \\
\end{tabular}

Data are represented as mean $\pm \mathrm{SD}$, Statistical analysis is carried out by two-way analysis of variance using COSTAT program, Unshared letters between brackets were a significant value between groups.

\section{Antiviral activity}

The antiviral and cytotoxic activities of the described sterols were tested for antiviral activity against the avian influenzaH5N1 virus, and the results were illustrated in table (4) and fig. (1). The results in table (4) and fig. (1) Showed that, M. paniculata sterols have high inhibition $\left(\mathrm{IC}_{50}=0.15\right.$ of $\left.\mu \mathrm{g} / \mathrm{ml}\right)$ than $R$. graveolens sterols $\left(\mathrm{IC}_{50}=\right.$ 7.8 of $\mu \mathrm{g} / \mathrm{ml}$ ) and this may be due to that $R$ graveolens more cytotoxic than M. paniculata.

The causative agents of the most fatal diseases are viruses, such as herpes simplex, AIDS and cancer [38]. Available medications for infectious diseases have always been limited. The results of the present study give conclusive evidence that $M$. paniculata sterols and $R$. graveolens sterols have antiviral activity against avian influenza H5N1 virus and this may be due to high phytosterol content.

These results concord with the results by Malini and Vanithakumari [39] and Khan et al. [40] who found that plant sterols are helping to combat the chronic viral infections. Other studies by Wachsman et al. [41, 42] found that the brassinosteroid and its derivatives inhibited the in vitro replication of herpes simplex type 1 (HSV-1) thymidine kinase (TK)+ and TK-strains.

Table 4: $\mathrm{TC}_{50}$ and antiviral activity $\left(\mathrm{IC}_{50}\right.$ ) of the tested compounds against $\mathrm{H} 5 \mathrm{N1}$ virus

\begin{tabular}{lll}
\hline Extract & TC $_{50}$ Conc. $(\mathbf{m g} / \mathbf{m l})$ & $\mathbf{I C}_{50}$ Conc. $(\boldsymbol{\mu g} / \mathbf{m l})$ \\
\hline M. paniculata & 0.54 & 0.15 \\
R. graveolens & 0.12 & 7.80 \\
\hline
\end{tabular}

Where, $\mathrm{TC}_{50}$ : the concentration which exhibited $50 \%$ cytotoxicity; $\mathrm{IC}_{50}$ : the half maximal inhibitory concentration.

A

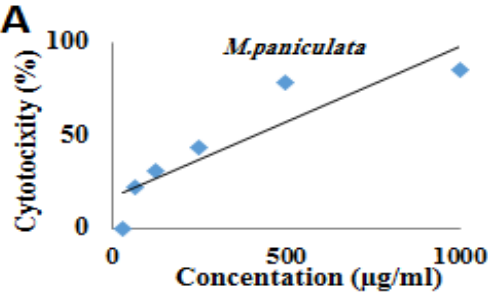

B

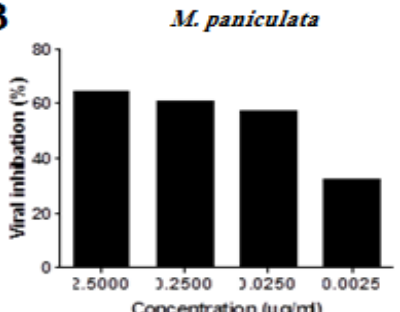

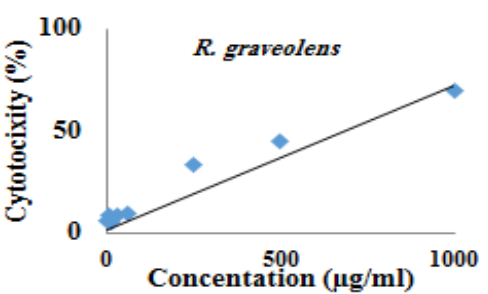

R. graveolens

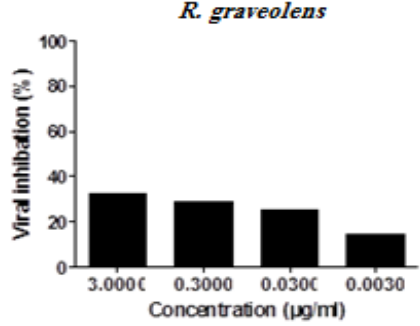

Fig. 1: Cytotoxicity (A) and antiviral (B) activities of M. paniculata and R. graveolens sterols

\section{Anti-tumor activity}

The anticancer properties of two Ruteace sterols using different cancer cell lines were studied. The results presented in table (5) showed that $R$. graveolens extract reduced the viability of treated cancer cells in a dose-dependent manner. Based on the cell viability measured after only $24 \mathrm{~h}$, the approximate $50 \%$ inhibitory concentration $\left(\mathrm{IC}_{50}\right)$ of $R$. graveolens sterols was 
approximately $32.3 \mu \mathrm{g} / \mathrm{ml}$ (A549 cells) with inhibition $81 \%$ at $100 \mu \mathrm{g} / \mathrm{ml}, 58.3 \mu \mathrm{g} / \mathrm{ml}$ (MCF7) with inhibition $84.3 \%$ at 100 $\mu \mathrm{g} / \mathrm{ml}$. While, M. paniculata sterols showed $77.3 \%$ inhibition against A549 cells.

Table 5: Antitumor activity of sterol fraction of $R$. graveolens and M. paniculata against cancer cell lines (HCT116, MCF7, HepG2 and A549)

\begin{tabular}{|c|c|c|c|c|c|c|c|c|}
\hline \multirow[t]{2}{*}{ Cancer cell lines } & \multicolumn{4}{|c|}{ Sterols fraction of $M$. paniculata $(\mu \mathrm{g} / \mathrm{ml})$} & \multicolumn{4}{|c|}{ Sterols fraction of $R$. graveolens $(\mu \mathrm{g} / \mathrm{ml})$} \\
\hline & HCT116 & MCF7 & HePG2 & A549 & HCT116 & MCF7 & HepG2 & A549 \\
\hline Inhibition $\% 100 \mu \mathrm{g} / \mathrm{ml}$ & 0 & 36.5 & 16.8 & 77.3 & 47.6 & 84.3 & 34.8 & 81 \\
\hline $\mathrm{IC}_{50} \mu \mathrm{g} / \mathrm{ml}$ & 0 & - & - & 65.1 & - & 58.3 & - & 32.3 \\
\hline $\mathrm{IC}_{90} \mu \mathrm{g} / \mathrm{ml}$ & 0 & - & - & 106.8 & - & 94.7 & - & 56.8 \\
\hline
\end{tabular}

Where, $\mathrm{IC}_{90}$

The present results confirmed the antitumour activity of $R$. graveolens sterols which in agreement with Fadlalla et al. [43] who found that $R$. graveolens extract contain biologically active compounds which have potent anti-cancer activity, exhibited through strong anti-survival effects on cancer cells. While M. paniculata came in the second rank and give $\mathrm{IC}_{50} 65.1 \mu \mathrm{g} / \mathrm{ml}$ (A549 cells) with inhibition $77.3 \%$ at $100 \mu \mathrm{g} / \mathrm{ml}$. In these regards, Choi et al. [44] and Lopes et al. [45] found that phytosterols have anti-cancer effects, against stomach cancer [46], lung cancer [47], ovary [48] and breast cancer [49] by enhancing stimulation of X-receptor and switch of sphingomyelin, suppression of cell division and induce apoptosis by activation of caspase [50]. It has been speculated that phytosterols inhibit cancer-cell growth, metastasis, invasion, and induce apoptosis [51]. Some epidemiological results suggest a correlation between sterol intake and a reduction in cancer risk. It has been estimated that phytosterols intake may be related to a reduction in cancer risk upwards of 20\% [52]. Chai et al. [53] found that $\beta$-sitosterol could inhibit the MCF-7 cells proliferation, also showed apoptosis activities in human leukemic U937 cells and human breast cancer MDA-MB-231 cells by activating of caspase- 3 and $\mathrm{Bax} / \mathrm{Bcl}-2$ ratio $[54,55]$.

\section{CONCLUSION}

R. graveolens and M. paniculata sterols contain bioactive compounds that open door for the treatment of many diseases such as inflammation, cancer, oxidation and viral infection which can be further explored for their potent use in pharma industries.

\section{CONFLICT OF INTERESTS}

Declared none

\section{REFERENCES}

1. Lavanya R, Maheshwari SU, Harish G, Raj JB, Kamali S, Hemamalani $\mathrm{D}$, et al. Investigation of in vitro anti-inflammatory, antiplatelet and arthritic activities in the leaves of Anisomeles malabarica L. Res J Pharm Biol Chem Sci 2010;1:745-52.

2. Harsha SN, Latha BV. In vitro antioxidant and in vitro antiinflammatory activity of Ruta graveolens methanol extract. Asian J Pharm Clin Res 2011;5:32-5.

3. Ratheesh M, Shyni GL, Sindhu G, Helen A. Protective effects of isolated polyphenolic and alkaloid fractions of Ruta graveolens L. on acute and chronic models of inflammation. Inflamm 2010;33:18-24.

4. Van Huyssteen M, Milne PJ, Campbell EE, van de Venter M. Antidiabetic and cytotoxicity screening of five medicinal plants used by traditional African health practitioners in the Nelson Mandela Metropole, South Africa. Afr J Tradit Complementary Altern Med 2011;8:150-8.

5. Meepagala KM, Schrader K, Wedge DE, Duke OS. Algicidal and antifungal compounds from the roots of Ruta graveolens and synthesis of their analogs. Phytochemicals 2005;66:2689-95.

6. Khouri NA, El-Akawi Z. Antiandrogenic activity of Ruta graveolens $\mathrm{L}$ in male Albino rats with emphasis on sexual and aggressive behavior. Neuroendocrinol Lett 2005;26:823-9.

7. Chávez M, Franco I, Tlatenco GM. Tradition and Herbal Remedies. Mexico City: Ce-Ácatl, AC; 2003. p. 80-1.

8. Browner $\mathrm{CH}$. Plants used for reproductive health in Oaxaca, Mexico. Econ Bot 1985;39:482-504.
9. Atta $\mathrm{AH}$, Alkofahi A. Antinociceptive and anti-inflammatory effects of some Jordanian medicinal plant extracts. J Ethnopharmacol 1998;60:117-24.

10. Mancebo F, Hilje L, Mora GA. The biological activity of Ruta chalepensis (Rutaceae) and Sechium pittieri (Cucurbitaceae) extracts on Hypsipyla grandella (Lepidoptera: Pyralidae) larvae. Rev Biol Trop 2001;49:501-8.

11. Sallal AJ, Alkofahi A. Inhibition of the hemolytic activities of snake and scorpion venoms invitro with plant extracts. Biomed Lett 1996;53:211-5.

12. Barbosa FS, Leite GLD, Alves SM, Nascimento AF, D'Ávila VA, Costa CA. Insecticide effects of Ruta graveolens, Copaifera langsdorffii and Chenopodium ambrosioides against pests and natural enemies in commercial tomato plantation. Maringa 2011;33:37-43.

13. Junghanns KT, Kneusel RE, Groger D, Matern U. Differential regulation and distribution of acridone synthase in Ruta graveolens. Phytochemicals 1998;49:403-11.

14. SLTC, The Society of Leather Traders Chemists Official methods of Analysis; 1963.

15. Arnao MB, Cano A, Acosta M. The hydrophilic and lipophilic contribution to total antioxidant activity. Food Chem 2001;73:239-44.

16. Ye ZW, Jiang JG, Wu GH. Biosynthesis and regulation of carotenoids in Dunaliella: progresses and prospects. Biotechnol Adv 2008;26:352-60.

17. Prieto P, Pineda M, Aguilar M. Spectrophotometric quantitation of antioxidant capacity through the formation of a phosphomolybdenum complex: specific application to the determination of Vitamin E. Anal Biochem 1999;269:337-40.

18. Rahman H, Eswaraiah MC, Dutta AM. In vitro anti-inflammatory and anti-arthritic activity of Oryza sativa Var. Joha Rice (An Aromatic Indigenous Rice of Assam). Am-Eurasian J Agric Environ Sci 2015;15:115-21.

19. Rashad AE, Shamroukh AH, Abdel-Megeid RE, Mostafa A, ElShesheny R, Kandeil A, et al. Synthesis and screening of some novel fused thiophene and thienopyridine derivatives for antiavian influenza virus (H5N1) activity. Eur J Med Chem 2010;45:5251-7.

20. Hayden FG, Cote KM, Douglas RG. Plaque inhibition assays for drug susceptibility testing of influenza viruses. Antimicrob Agents Chemother 1980;17:865-70.

21. Mosmann T. Rapid colorimetric assays for cellular growth and survival: application to proliferation and cytotoxicity assays. J Immunol Methods 1983;65:55-63.

22. Thabrew MI, Hughes RD, McFarlane IG. Screening of hepatoprotective plant components using a HepG2 cell cytotoxicity assay. J Pharm Pharmacol 1997;49:1132-5.

23. El-Menshawi BS, Fayad W, Mahmoud K, El-Hallouty SM, ElManawaty $\mathrm{M}$, Olofsson $\mathrm{MH}$, et al. Screening of natural products for therapeutic activity against solid tumors. Indian J Exp Biol 2010;48:258-64.

24. Matthausa B, Özcanb MM. Chemical evaluation of citrus seeds, an agro-industrial wastes a new potential source of vegetable oil. Grasas Aceites 2012;63:313-20.

25. Woyengo TA, Ramprasath VR, Jones PJH. Anticancer effects of phytosterols. Eur J Clin Nutr 2009;63:813-20. 
26. Raju MP, Babu DG, Kumar BR, Rajashekar $\mathrm{CH}$. The role of phytosterols enriched foods-a review. J Environ Sci Toxicol Food Technol 2013;7:40-7.

27. Halliwell B. Antioxidants in human health and disease. Ann Rev Nutr 1996;16:33-50.

28. Valantina RS, Neelamegam P. Selective ABTS and DPPH-radical scavenging activity of peroxide from vegetable oils. Int Food Res J 2014;22:289-94

29. Gautam MK, Gupta A, Rao CV, Goel RK. Antihyperglycemic and antioxidant potential of Murraya paniculata linn. leaves: a preclinical study. J Pharm Res 2012;5:1334-7.

30. Rodríguez EJ, Ramis-Ramos G, Heyden YV, Simó-Alfonso EF, Lerma-García MJ, Saucedo-Hernández Y, et al. Chemical composition, antioxidant properties and antimicrobial activity of the essential oil of Murraya paniculata leaves from the mountains of Central Cuba. Nat Prod Commun 2012;7:1527-30.

31. Mita TA, Shihan MH, Rahman M, Sharmin T, Maleque M, Alvi $\mathrm{MR}$, et al. In vitro antioxidant, cytotoxic, thrombolytic, antimicrobial and membrane stabilising activities of Murraya paniculata. Am J Res Commun 2013;1:226-37.

32. Chen CH, Chan HC, Chu YT, Ho HY, Chen PY, Lee TH, et al. Antioxidant activity of some plant extracts towards xanthine oxidase, lipoxygenase and tyrosinase. Molecules 2009;14:2947-58.

33. Haraguchi H. Antioxidative plant constituents. In: Tingali C. Ed. Bioactive compounds from natural sources. New York: Taylor and Francis Inc; 2001. p. 339-77.

34. Harsha SN, Latha BV. In vitro antioxidant and in vitro antiinflammatory activity of Ruta Graveolens methanol extract. Asian J Pharma Clin Res 2012;5:32-5.

35. Gupta NB, Hath R, Srivastava N, Shanker K, Kishor K, Bhargava KP. Anti-inflammatory and antipyretic activities of $\beta$-sitosterol. Planta Med 1980;39:157-63.

36. Prieto JM, Recio MC, Giner RM. Anti-inflammatory activity of $\beta$ sitosterol in a model of oxazolone-induced contact-delayedtype hypersensitivity. Bol Latinoam Caribe Plant Med Aromat 2006;5:57-62.

37. Laidlaw M. Pilot study conducted at The University of Guelph, by the human nutraceutical research unit on the supplement Sterol $117^{\mathrm{TM}} ; 2005$

38. Mayer AMS. Therapeutic implications of microglia activation by lipopolysaccharide and reactive oxygen species generation in septic shock and central nervous system pathologies: a review. Medicina (Buenos Aires) 1998;58:377-85.

39. Malini T, Vanithakumari G. Rat toxicity studies with $\beta$ sitosterol. J Ethnopharmacol 1990;28:221-34.

40. Khan MM, Jain DC, Bhakuni RS, Zaim M, Thakur RS. The occurrence of some antiviral sterols in Artemisia annua. Plant Sci 1991;75:161-5.

41. Wachsman MB, López MF, Ramirez JA, Galagovsky LR, Coto CE. Antiviral effect of brassinosteroids against herpes virus and arenaviruses. Antiviral Chem Chemother 2000;11:71-7.
42. Wachsman MB, Ramirez JA, Galagovsky LR, Coto C. Antiviral activity of brassinosteroids derivatives against measles virus in cell cultures. Antiviral Chem Chemother 2002;13:61-6.

43. Fadella K, Watson A, Yehualaeshet T, Turner T, Samuel T. Ruta Graveolensextract induces DNA damage pathways and blocks akt activation to inhibit cancer cell proliferation and survival. Anticancer Res 2011;31:233-41.

44. Choi J, Lee E, Lee H, Kim K, Ahn K, Shim B, et al. Identification of campesterol from Chrysanthemum coronarium $\mathrm{L}$ and its antiangiogenic activities. Phytother Res 2007;21:954-9.

45. Lopes G, Sousa C, Valentao P, Andrade PB. Sterols in algae and health. Plant Animal Sources 2013;10:7-15.

46. De Stefani E, Boffetta P, Ronco AL, Brennan P, Deneo-Pellegrini $\mathrm{H}$, Carzoglio JC, et al. Plant sterols and risk of stomach cancer: a case-control study in uruguay. Nutr Cancer 2000;37:140-4.

47. Mendilaharsu M, de Stefani E, Deneo-Pellegrini H, Carzoglio J, Ronco A. Phytosterols and risk of lung cancer: a case-control study in Uruguay. Lung Cancer 1998;21:37-45.

48. McCann SE, Freudenheim JL, Marshall JR, Graham S. Risk of human ovarian cancer is related to dietary intake of selected nutrients, phytochemicals and food groups. J Nutr 2003;133:1937-42.

49. Ju YH, Clausen LM, Allred KF, Almada AL, Helferich WG. $\beta$ Sitosterol, $\beta$-sitosterol glucoside, and a mixture of $\beta$-sitosterol and b-sitosterol glucoside modulate the growth of estrogen responsive breast cancer cells in vitro and ovariectomized athymic mice. J Nutr 2004;134:1145-51.

50. Bradford PG, Awad AB. Modulation of signal transduction in cancer cells by phytosterols. Biofactors 2010;36:241-7.

51. Meric J, Rottey S, Olaussen K, Soria J, Khayat D, Rixe 0, et al. Cyclooxygenase- 2 as a target for anticancer drug development. Crit Rev Oncol Hematol 2006;59:51-64.

52. The American Institute for Cancer Research (AICR). Plant Compound Continue to Challenge Science. AICR; Washington, DC, USA; 2006.

53. Chai JW, Kuppusamy UR, Kanthimathi MS. Beta-sitosterol induces apoptosis in MCF-7 cells. Malays J Biochem Mol Biol 2008;16:28-30.

54. Awad AB, Downie AC, Fink CS. Inhibition of growth and stimulation of apoptosis by beta-sitosterol treatment of MDAMB-231 human breast cancer cells in culture. Int J Mol Med 2000;5:541-6.

55. Park C, Moon DO, Rhu CH, Choi BT, Lee WH, Kim GY, et al. $\beta$ sitosterol induces antiproliferation and apoptosis in human leukemic U937 cells through activation of caspase- 3 and induction of Bax/Bcl-2 ratio. Biol Pharm Bull 2007;30:1317-23.

\section{How to cite this article}

- Doha H Abou Baker, Eman A. Ibrahim, Ahmed Kandeil, Farouk K EL-Baz. Sterols bioactivity of Ruta graveolens L. and Murraya paniculata L. Int J Pharm Pharm Sci 2017;9(2):103-108. 